\title{
Dvokrilnost istine u Divljoj patki: Platon, Ibsen i Krleža"
}

Abstract: Tomljenović Ana, Dvokrilnost istine u Divljoj patki: Platon, Ibsen i Krleža (The Two Winged Truth in The Wild Duck: Plato, Ibsen, and Krleža). "Poznańskie Studia Slawistyczne" 20. Poznań 2021. Publishing House of the Poznań Society for the Advancement of the Arts and Sciences, Adam Mickiewicz University, pp. 215-235 . ISSN 2084-3011.

Questioning the commonly held assumption in critical reception that Ibsen's symbol of the wild duck was influenced by Darwin's theory, I want to argue that the wild duck flew into Ibsen's play all the way from Plato's aporetic dialogue The Theaetetus. Following Lacan's reading of Plato, I want to examine the connection between the Socratic position towards knowledge - especially the rupture between knowledge and truth - and the treatment of dramatic dialogue in Ibsen's The Wild Duck and Krleža's The Glembays.

Keywords: Ibsen; Plato; Krleža; dialogue; knowledge

LEONE: Ne mogu riječi svoje loviti natrag kao vrapce

(Krleža, 1962, 84)

U opsežnoj studiji Ciklus o Glembajevima u svom evropskom kontekstu (1975) Ivo Vidan kratko se osvrće na „sjevernjačko[] osvjetljenj[e]” (Vidan, 1975, 465) Krležine drame uočivši „niz podudarnosti” između Divlje patke i Gospode Glembajevih „koje pokazuju da je Ibsen Krleži stvaralački možda najviše značio tamo gdje mu je problematika najkompleksnija" (Vidan, 1975, 467). Pitajući se nije li ,apstraktna istinoljubljivost Gregersa Werlea u Divljoj patki istog karaktera kao Leoneova" (Vidan, 1975, 467), Vidan nam svojim komentarom nudi putokaz koji ćemo slijediti pri usporednom tumačenju izdvojenih dramskih tekstova. Oslanjajući se pritom

* Ovaj je rad sufinancirala Hrvatska zaklada za znanost projektom IP-2018-01-7020 „Književne revolucije”. 
na kritičke osvrte koji su naročitu pozornost posvetili analizi Gregersove osebujne retorike i uopće njegova kompleksnog odnosa prema jeziku, u interpretaciji koja slijedi pokušat ćemo povezati apstraktnu istinoljubivost Ibsenova i Krležina protagonista sa specifičnim položajem koji zauzimaju u odnosu spram Drugoga, kao i sa začudnim jezičnim postavom koji njihovi sugovornici ne znaju kako bi drukčije nazvali nego prenapetim.

Da je istinoljubivost ili ljubav prema istini tijesno vezana uz određenu psihičku strukturu dade se naslutiti iz opisa „nervn[e] indispozicij[e]” (Krleža, 1962, 83) Ibsenova i Krležina junaka. Svjestan da je Gregers „kompliciran slučaj” (Ibsen, 1978a, 311), liječnik Relling dijagnosticirao mu je bolest neobična naziva i nesigurne etiologije - kako tvrdi u trećem činu: ,[o]n pati od akutne groznice pravičnosti” (Ibsen, 1978a, 289). Budući da je, prema doktorovu mišljenju, riječ o poremećaju koji ga ne svrstava ni u jednu psihopatološku kategoriju, premda je „momak” nedvojbeno „uvrnut, lud i šašav” (Ibsen, 1978a, 289) Relling nam daje naslutiti krajnju ambivalentnost Gregersovih duševnih osobina: liječnik naime smatra da Gregers ,[n]ije ništa luđi nego što su to ljudi općenito”, premda sa sigurnošću tvrdi da je „bolest [...] u njemu” (Ibsen, 1978, 289). Rellingova dijagnoza tako prati jednako nepreciznu terminologiju staroga Werlea, koji sinovo povišeno stanje iznova imenuje terminom overspcendt - pojmom u kojem već Ivo Vidan naslućuje ključnu poveznicu između Ibsenova i Krležina neugodnog i neuravnoteženog osobenjaka. Polazeći od nalaza liječnika, prema kojem je Werleovo oboljenje svojstveno zdravim pojedincima, odnosno prema kojem je njegov poremećaj posve normalan u općoj populaciji, u nastavku ćemo pokušati pokazati kako se groznica koja karakterizira svako biće koje govori proširila u književnim i filozofskim dijalozima, posebice među sugovornicima koji njeguju ljubav prema istini.

Pojam kojim se opisuje Gregersovo duševno stanje - a koji u norveškom jeziku glasi overspaendt, u njemačkom prijevodu überspannt, u engleskom high-strung (cf. Ibsen, 1978b, 408, 410), a u hrvatskom egzaltiran odnosno opterećen (cf. Ibsen, 1987; 1978a, 254) - Errol Durbach vezuje uz ,niz pred-frojdističkih nastojanja da se opiše psihički život” odnosno uz težnju da se približe rubna raspoloženja prenapetosti, histerije ili neuroze (cf. Durbach, 2009, 51). Budući da i u Ibsenovoj i u Krležinoj drami susrećemo, Fabriczijevim riječima, protagoniste koji se vladaju ,tako neobuzdano nervozno, da time djeluj[u] upravo zarazno" (Krleža, 1962, 35), 
valja nam pomnije ispitati je li doista Leoneova i Gregersova groznica iste vrste $\mathrm{i}$ istoga podrijetla, odnosno istražiti zašto se doima da je upravo prisutnost neistine u jeziku ključni otponac njihove bolesti te naposljetku objasniti zašto se u oba slučaja njihova nervoza ${ }^{1}$ prenosi ženskom linijom nasljeđivanja.

Raspravljajući o poimanju istine u psihoanalizi, Lacan u seminaru naslovljenom Druga strana psihoanalize (1969-1970) tumači kako se u položaju histerika dade raspoznati posebna ,ljubav prema istini” (Lacan, 2007, 52), ljubav koja - vrijedi naglasiti - ide ruku pod ruku s osjećajem dubokog prijezira prema označitelju. Strastveno obuzet istinom, histeričar ne priznaje istinu koja se nudi riječima, on hoće pravu istinu kao „istinitu istinu”, a koju označitelj „promašuje samim činom formuliranja istine” (Zupančič, 2006, 166). Dokazujući kako „istina nije [...] lako dostupna”, Lacan je uspoređuje s „određenim pticama” koje se „mogu uloviti jedino tako da im se stavi soli na rep" (Lacan, 2007, 55). Budući da istina za Lacana nipošto nije laka lovina, ne možemo joj pristupiti, kako bi htjeli pojedini Ibsenovi ili Krležini likovi, kroz iskrena priznanja ili izravne izjave. Pa čak i ako čvrsto odlučimo, riječima Hjalmara Ekdala, svoje odnose temeljiti „na punom povjerenju, na potpunoj i obostranoj iskrenosti” te graditi vezu u kojoj „ništa ne skriva[mo] jedno od drugoga”, u kojoj „nema nikakve tajne" (Ibsen, 1978a, 302), ništa se bliže zbog toga nećemo primaknuti istini - istina i dalje ostaje na drugoj strani priče kao drugoj polovici označiteljske mreže. Ponudivši formulu kojom obuhvaća naš položaj

${ }^{1}$ Prema glasovitom tumačenju Huga Klajna, Krleža pripada književnicima koji „podrobnije govor[e] o neurotičnom simptomu svog lika ili o njegovom snu” pa tako o Leoneovu „slučaj[u]” među ostalim doznajemo da su ga „od njegove rane mladosti [...] smatrali neuravnoteženim (überspannt), slali su ga u sanatorije, otac mu u jednom trenutku kaže da će «svršiti u ludnici», a po jednom podatku u genealogiji dodatoj Krležinoj prozi Glembajevi, on posle napada na svoju maćehu zaista provede izvesno vreme u bolnici za duševne bolesti" (Klajn, 1968, 114). Dok Hugo Klajn na primjeru Leonea oslikava klinički portret neuroze, Arbanas i Kreho razmatraju Leoneov slučaj kao psihijatrijski primjer sumanutog poremećaja koji karakterizira ,zabluda nastala na bolesnoj osnovi i nedostupna korekciji, u koju osoba čvrsto vjeruje i nikakvim racionalnim i logičnim objašnjenjima ne može se razuvjeriti” (Arbanas, Kreho, 2019, 43). 
naspram istine u jeziku, a koja glasi ,[n]emamo ne-odnos s istinom” (Lacan, 2007, 58), Lacan će istinu smjestiti, da ostanemo pri ornitološkim metaforama, uvijek u krilo Drugoga.

Nakon što je obrazložio usporedbu potrage za istinom s lovom na ptice, Lacan navodi njezino književno izvorište - kada je kao dijete tek započeo čitati, dobio je zbirku u kojoj je naslov prve pripovijesti glasio Priča o pola pileta. Zanimljivo je istaknuti da u svojoj nekadašnjoj, djetinjoj opčinjenosti pilećom polovicom, komadom, rasjekom, Lacan prepoznaje zametak psihoanalitičke doktrine koju će čitav život izgrađivati, a koju u ovom kontekstu prikladno označava imenom Priča o pola subjekta (cf. Lacan, 2007, 55). Iz priče o piliću kojem nedostaje druga strana rađa se dakle, kao iz jajeta, Lacanova koncepcija ne-sve istine - istine koja je „dostupna samo kao polu-rečena [mi-dire]" (Lacan, 2007, 51), istine koja nam je, iako je nismo mislili kazati, iz usta izletjela.

Budući da Gregersovi prenapeti pogledi stoje u tijesnoj vezi s njegovim životnim poslanjem - on je naime preuzeo ulogu pronositelja istine i lučonoše pravde - njegovo se moralno i spoznajno čistunstvo dade usporediti s misijom Thomasa Stockmanna iz Neprijatelja naroda (1882), drame koja neposredno prethodi Divljoj patki. Kao i u slučaju liječnika Stockmanna, Gregersova temeljna zabluda - opsjena iz koje proizlazi i tragikomičnost njegova lika - tiče se uvjerenja da se istina dade uhvatiti i za glavu i za rep kao što lovci u drami hvataju ptice: patke, golubove, kokoši. Usuprot dominantnim čitanjima Ibsenova djela, istina u njegovim dramama niti je bliska, niti dosupna, a najmanje je, kao što ćemo vidjeti, cijela. Slijedom Platonove metafore znanja o istini, kao ptica koju je Ibsen ugnijezdio u središte Divlje patke, istina će nam se se pokazati kao dvokrilna i divlja, raspolovljena i ranjena.

Imamo li naime na umu da je istina koja se u Divljoj patki i u Glembajevima nastoji iznijeti na vidjelo istina koja se u konačnici tiče odnosa spolova, ljubav prema istini kojom smo započeli diskusiju odvest će nas nužno prema istini o ljubavi. Da se Ibsen u Divljoj patki iznova vraća zagonetki odnosa između dvoga, raspoznajemo već iz prve replike u kojoj jedan sluga poziva drugoga da posluša što slijedi jer je stari Werle ustao da održi „zdravicu gospođi Sørbi” (Ibsen, 1978a, 239), njegovoj sadašnjoj domaćici i, kako se nagađa, ljubavnici. Nakon što mu ovaj uzvraća pitanjem: „Je li istina ono što ljudi govore, da ima nešto među 
njima?”, prvi sluga odgovara: „A vrag bi [ga] znao” (Ibsen, 1978a, 239). Osim toga, Werleova strastvena potraga za istinom koja će uslijediti ubrzo nakon gozbe, istinom o tome je li postojala veza između njegova oca te njihove nekadašnje domaćice Gine Hansen, zrcali se u preispitivanju ljubavnih odnosa barunice Castelli - između Leonea i barunice Castelli, Ignjata i barunice Castelli, Silberbrandta i barunice Castelli, tajnika Skomraka i barunice Castelli itd.

Nakon što je više od petnaest godina proveo u osami Høidala, „tamo gore u [...] šumama i pustinji” (Ibsen, 1978a, 280) - okorjeli neženja Gregers Werle, pristigavši u društvo, među ljude, odlučuje druge podučiti odnosu, vezi, braku: kako ostvariti brak u njegovoj punini, kako uspostaviti ljubavni odnos koji je zavrijedio da se nazove istinskim - kako ,zasnovati sasvim novo življenje - življenje kao zajednički život u istini i bez tajni” (Ibsen, 1978a, 296). Iako priznaje da nikad nije upoznao par čija bi veza odgovarala njegovoj viziji bračnog zajedništva², vidio je zato, kako kaže: „bezbroj brakova one druge vrste” (Ibsen, 1978a, 297). Aludirajući pritom na nesretni brak svojih roditelja, Gregers tvrdi da je da imao priliku ,,izbliza [...] vid[jeti] šta sve jedan takav brak može da sruši u ljudima" (Ibsen, 1978a, 297). Uvjeren da se u braku može doživjeti savršen sklad kao što se u jeziku može postići čist račun, Gregers objašnjava svome oženjenom drugu kako nema istinskog odnosa bez savršenoga dijaloga: muž i žena trebali bi prema tome ne samo kazati „sve” jedno drugome nego i shvatiti „sve” što je onaj drugi rekao. Kada se Hjalmar, po Gregersovu nagovoru, odvažio zatražiti svoju suprugu da iznese sve na vidjelo, da mu prizna istinu o djetetu, diskusija supružnika pokazat će se besplodnom, a dijalog nemoguć:

HJALMAR: Moraš mi odgovoriti na ovo jedino pitanje! Pripada

li Hedvig meni - ili - ? No?

GINA (gleda ga s hladnim prkosom): Ja ne znam.

HJALMAR (drhteći): Ti ne znaš!

GINA: Odakle ja da znam? Ovakva jedna kao što sam ja - (Ibsen, 1978a, 305).

${ }^{2}$, ,RELLING: [...] Pardon gospodine Werle, koliko ste vi - onako od oka - koliko ste tih istinskih brakova već vidjeli u svom životu?

GREGERS: Vjerujem da sam jedva i jedan jedini vidio.

RELLING: Nisam ni ja" (Ibsen, 1978a, 297). 
Iako dakle središnje pitanje ostaje neodgovoreno, a istina trajno nedokučiva, iz dijaloga Gregersa i Håkona Werlea naslućujemo da se istina o kojoj nema ni zapisa ni spomena ipak dade naslutiti između riječi i između redaka:

WERLE: Ti se smiješ? Možda misliš da ne govorim istinu? Naravno, toga nema u mojim knjigama - takvi izdaci se nikad ne uvode u knjige.

GREGERS (smiješi se hladno): Svatko, ima izdataka koji se radije ne unose u knjige. WERLE (ustukne): Šta hoćeš da kažeš?

GREGERS (skupi hrabrost): Jesi li uveo u knjige i to koliko je koštalo Hjalmarovo učenje fotografskog zanata?

WERLE: Ja? Zašto da to unosim u knjige?

GREGERS: Pa, sada znam da si to ti platio. A znam i to, da si ti bio taj koji mu je tako izdašno pomogao da otpočne novi život.

WERLE: No - i onda još kažeš da nisam dovoljno učinio za Ekdalove! Mogu ti reći da su mi ti ljudi dosta izdataka napravili.

GREGERS: I o tim izdacima nisi vodio nikakve knjige? (Ibsen, 1978a, 250).

Kao i u Lacanovoj glasovitoj tvrdnji, prema kojoj se odnos spolova ne prestaje ne ispisivati, istina se o odnosu spolova u Ibsena ne uspijeva ne upisati u knjige. Unatoč tome što istina o vezi i spoju između dvoga izrijekom ostaje izvan knjigovodstvenih korica, Gregers nagađa o njoj iz drugog pisanog dokumenta, iz poslovnog pisma koje mu je otac posalo i uz koje je, kao post scriptum, stajala kratka napomena da se Hjalmar oženio. Budući da je otac u dodatku naznačio tek da se Hjalmar Ekdal vjenčao „s izvjesnom gospođicom Hansen”, Gregers ga optužuje da je lukavo prešutio njezino puno ime jer nije ,ništa napisao o tome, da je ta gospođica Hansen - Gina Hansen, [njihova] nekadašnja domaćica” (Ibsen, 1978a, 250). Kao što je Gregers optužio svoga oca, veletrgovca Werlea, da ne provodi sve primitke i izdatke kroz knjige, da pojedine stavke ostaju nezabilježene, tako i Leone Glembay opetovano upozorava svoje sugovornike da „ima stvari koje nisu zapisane ni u kaznenom zakonu ni u cestoredarstvenom redu" (Krleža, 1962, 62). Budući da Leone neprestano ukazuje da postoji nešto što izmiče poretku označitelja, ,da označitelj nikada ne uspijeva posvjedočiti o istini” (Zupančić, 2006, 167), u njegovu se diskursu dade raspoznati histeričko, ,nepovjerenje u simboličko (jezika) kao medij istine" (Zupančič, 2006, 167) o čemu najjasnije svjedoči tvrdnja: „Ja mislim, u jednu riječ, da sve vaše riječi ne stoje ni u kakvoj vezi sa samim događajem!" (Krleža, 1962, 62). Nasuprot Pubinim ,juridičkim [...] 
vicevima" (Krleža, 1962, 66) koji posve iskrivljuju i izokreću stvar, Leone istinu smješta na drugu stranu zakona označitelja, na neuhvatljivu drugu polovicu riječi. Tvrdeći kako juridički, medicinski i religijski diskurs ${ }^{3}$ na isti način zaobilaze istinu, Leone zaključuje: „Nikada nisam ni jednom advokatu ni doktoru vjerovao ni slova!” (Krleža, 1962, 66).

Paralelno s tragičnim ishodom, smrću djeteta kao ploda ljubavi, Divlja patka završava najavom vjenčanja između udovice Sørbi i starog Werlea. Upravo na primjeru posljednje u nizu ljubavi vremešnog i oslijepljelog Werlea Hjalmar raspoznaje onu vrstu muško-ženskog odnosa o kojem Gregers nadahnuto propovijeda. Budući da odnos ,zasnivaju na punom povjerenju, na potpunoj i obostranoj iskrenosti” te da ,nema nikakve tajne u njihovom odnosu", Hjalmar zaključuje da su time osigurani svi uvjeti ,da se osnuje istinski brak" (Ibsen, 1978a, 302). Imamo li na umu međutim da je stari Werle gotovo izgubio vid pa će Bertha, kako kazuje, ,pokušati da mu ustupi[] svoje oči”" (Ibsen, 1978a, 300), istinski odnos postaje moguć samo onkraj poretka sve istine, svega znanja i spoznaje, u svijetu u kojem vlada, da tako kažemo, ljubavno sljepilo.

Promotrimo li dakle sliku ljubavnog para kao paradigmu dijaloškog odnosa, u Ibsenovoj ćemo Divljoj patki pokazati kako se zagonetka odnosa spolova ne prestaje (ne) oslikavati počevši od metateatarske igre fotografskim aparatom koji je u drami Gina upalila samo jednom - kako bi uhvatila objekt koji se tijekom čitave drame nastoji osvijetliti, kako bi načinila snimku para, sliku dvoje mladenaca.

\section{$* * *$}

Nakon što se naime vratio kući poslije višegodišnjeg izbivanja te stigao na gozbu upriličenu njemu u čast, Gregers Werle optužuje svojega oca da je čitav život proveo u laži, okrivljujući ga za preljubnički odnos s domaćicom Ginom Hansen plod kojega je četrnaestogodišnja djevojčica Hedvig. Saznavši od majke za očevu nevjeru, Gregers starom Werleu na teret stavlja i majčinu smrt - ne može mu oprostiti ,patnje i uvrede koje je ona ovdje morala podnositi, sve dok je to nije slomilo i upropastilo"

${ }^{3}$ „LEONE: Ti i Silberbrandt i Puba savršeno ste slični. Za Silberbrandta je čitav problem u sedam sakramenata, za Pubu u cestoredarstvenom redu, a za tebe u štofvekslu!" (Krleža, 1962, 147). 
(Ibsen, 1978a, 251). Poput Ibsenova odmetnutog sina, i Leone pristiže nakon dugih jedanaest godina u obiteljski dom, na slavljenički banket u kojem zatječe pravo ibsenovsko ozračje ili, njegovim riječima kazano, „nezdrav[u] atmosfer[u] laži i intriga i histerije" (Krleža, 1962, 104). Suočivši se u vlastitom obiteljskom domu sa ženama koje su zamijenile njihove majke, i Gregersa i Leonea progoni osjećaj nepravde te se u njima javlja snažan poriv da iznesu na vidjelo istinu o međuljudskim odnosima koji su se odvijali pod njihovim obiteljskim krovom. Poveznica dviju drama na koju Vidan upućuje odnosi se na moguću istovrsnu „nesretnu bolest” (Ibsen, 1978a, 254) koja je u dramskoj prošlosti zadesila i Gregersovu i Leoneovu majku: poput prve gospođe Glembay, koja se „otrovala u eri skandala s [onom] pustolovkom" (Krleža, 1962, 110), prva gospođa Werle skončala je shrvana tugom zbog navodne brakolomne veze svojega supružnika. Suprotno mišljenju svojih sinova koji ih optužuju za smrt majki, stari Werle i stari Glembay smrt svojih supruga tumače u svjetlu njihove psihičke rastrojenosti - duševne boljke koju su po njihovu strogom uvjerenju Gregers ${ }^{4}$ i Leone naslijedili od voljenih majki:

GLEMBAY: Ostavi me, molim te, s tim svojim glupostima! Svi ste vi Daniellijevi psihopati, te na svojim suludim i bizarnim opažanjima gradite nekakve optužbe u zraku! Sve su to magle i paučine! Molim te! O svim tim tvojim dokazima i indicijama nema ni govora! Tvoja je mati prvi put digla ruku na sebe kad joj je bilo sedamnaest godina! Onda nije mene još ni poznavala! Tri je godine preležala po švicarskim Nervenanstaltima, a to su gospoda Daniellijevi preda mnom - naravno - lukavo, grčki, venecijanski zatajili! To je bila žena koja se abnormalno bojala mirisa ruža i tamne sobe. Ja se uopće ne sjećam egzistira li na svijetu nešto čega se ona nije bojala! Ona je cviljela od užasa ako su negdje zaboravili zatvoriti vrata! Htjela je jedamput da skoči s jurećeg šnelcuga još kad je tebe nosila, a gdje je onda bila još barunica Castelli? Idi, molim te! Sve ovo što ti buncaš bolesni su moždani! Das alles sind Hirngespinste nur! Ustvari, to je arogantno i okrutno spram tvog rođenog oca. Ti si kapriciozan neuropat, kakva ti je bila i mati! (Krleža, 1962, 110).

Kao i u Krležinu dijalogu oca i sina, Håkon Werle u sinovim riječima razabire majčine magle i paučine, izraz poremećena ženskog uma koji se poput tolikih drugih nasljednih bolesti iz Ibsenova opusa prenosi s koljena na koljeno, iz generacije u generaciju:

${ }^{4}$ „WERLE: [...] Tvoja savjest je bila bolesna još od djetinjstva. To je nasljeđe tvoje majke, Gregerse, jedino nasljeđe koje ti je ona ostavila" (Ibsen, 1978a, 288). 
WERLE: Gregerse, vjerujem da tebi ni jedan čovjek na svijetu nije tako odvratan kao ja. GREGERS (tiho): Suviše sam te izbliza gledao.

WERLE: Gledao si me očima svoje majke. (Malo spusti glas) Ali ne smiješ zaboraviti da su njene oči - ponekad bile zamagljene (Ibsen, 1978a, 253).

U nastavku dijaloga dvojice Werlea, Håkon će još jednom ponoviti: „[o]d riječi do riječi - kao da slušam tvoju majku” (Ibsen, 1978a, 254) majku čiju će ulogu Gregers neuspješno pokušati preuzeti odlučivši donijeti na svijet istinu o djetetu. Ne dovodeći ni trena u pitanje da su optužbe njegove bolesne majke o očevoj brakolomnoj vezi s domaćicom Ginom Hansen točne, Gregers u razgovoru s Hjalmarom Ekdalom, svojim nekadašnjim prijateljem, saznaje da su on i Gina supružnici te da su u braku dobili djevojčicu Hedvig. Nakon što je doznao da njegov otac dugi niz godina financijski pomaže obitelji Ekdal, da je zaposlio staroga Ekdala, školovao njegova sina Hjalmara te da ga je, na određeni način, gurnuo u krilo Gini Hansen, Gregers ni najmanje ne dvoji u kukavičju podvalu staroga Werlea: prema njegovu sudu mala Hedvig je Ginina i Werleova kći koju Hjalmar odgaja kao vlastito dijete. Uvjeren da se Hjalmar zapleo u mrežu laži i obmana, ne sluteći pri tome da je „ono, što naziva svojim domom, sazdano na laži”, Gregers kreće u herojsko-komički podvig, „zadatak" za koji se isplati živjeti, pothvat za koji i sam kazuje da možda može izazvati podsmijeh, ali kojemu je cilj veličanstveno dostignuće: drugome priopćiti i drugoga podučiti ljubljenoj istini (Ibsen, 1978a, 254). Kao što ističe Toril Moi u svojoj analizi, Gregers sada nastavlja poslanje koje je započeo u dramskoj prošlosti, kada je nastojao u očevom tvorničkom pogonu „uzdići duše radnika” (Moi, 2002, 665).

Budući da se muški plod spoznaje u Divljoj patki može i doslovno izjednačiti sa ženskim porodom, Ibsenova igra Platonovom metaforom tjelesnog kao duševnog stvaranja ovdje otkriva tragikomičnu jalovost istinoljublja: ne samo da se istina o djetetu propušta roditi nego se smrću djeteta u završnici komada slavi njezina krilata i aporetična priroda.

$* * *$

Da je istina poput djeteta, dvojna i dvodijelna, najjasnije se ogleda u ključnoj poveznici Ibsenova Gregersa i Krležina Leonea, u istovjetnoj strukturi njihova lika u kojoj se susreću dvije srodstvene linije poput dvaju 
krila ptice: majčina i očeva strana. Kao što ćemo nastojati pokazati u nastavku, sklop dvaju različitih dijelova koji se očituje, da se poslužimo $\mathrm{Kr}$ ležinim riječima, u spoju majčine i očeve rase (cf. Krleža, 1962, 104), venecijanske i glembajevske krvi, proizlazi iz opisa Sokrata kao Erosa u Platonovu Simpoziju, a koji se definira kroz prepletaj suprotstavljenih osobina svojih roditelja. Slučajno ili ne, Leone Glembay preko svoje majke Grkinje Irene Basilides-Danielli svoje podrijetlo vuče upravo od grčkih lukavaca i lažljivaca (Krleža, 1962, 110). Poput Gregersa Werlea, za kojeg ćemo u analizi tvrditi da predstavlja još jedno Ibsenovo poigravanje figurom Platonova Sokrata, Krležin Leone po svojoj tituli doktora filozofije pripada istoj rodoslovnoj liniji ljubitelja mudrosti. Da Gregersa Werlea možemo promatrati kao devetnaestostoljetnu verziju slavnog filozofa dade se naslutiti najprije iz položaja koji zauzima naspram svog druga-sugovornika, položaja koji se nedvosmisleno prikazuje kao oblik ,filozofskog vođenja" (Szlezàk, 2000, 81). Odlučivši naime preuzeti skrb za Hjalmarovu „bezazlenu[u], djetinj[u] duš[u]” (Ibsen, 1978a, 254), dušu za koju vjeruje da živi u neznanju o istini koju krije njegovo obiteljsko gnijezdo, Werle preuzima Sokratovo učiteljsko poslanje. Utoliko što je naumio odvesti Hjalmara na put do istinite spoznaje, Werle zapravo nastupa kao sljedbenik majeutike, odnosno nasljednik primaljske vještine Sokratove majke. Poput „vrsne i cijenjene primalje Fenarete” (Platon, 1979, 12) koja ženama pomaže prilikom poroda, Sokrat na jednak način služi svojim sugovornicima: omogućuje trudnim muškarcima da na svijet donose duhovno potomstvo, „plod [svoje] duše” (Platon, 1979, 14).

Shvatimo li Platonova Sokrata „kao književn[u] figur[u]” (Szlezàk, 2000, 22) u kojoj se isprepliću obilježja ružnog i lijepog, ozbiljnog i smiješnog, visokog i niskog, u liku Gregersa Werlea možemo raspoznati njegovo tragikomično preoblikovanje. Poput Sokratove pojave, kojoj se ,priznavalo da je izuzetno ružna” (Guthrie, 2006, 369), protagonist Divlje patke čuven je, još iz mladih dana dramske prošlosti, upravo po rugobi:

GINA: Je li Gregers još uvijek onako ružan?

HJALMAR: Pa, lijepo baš ne izgleda (Ibsen, 1978a, 258).

Kao što u Sokrata ružno lice sakriva ljepotu najviše vrste, Ibsenova drama nedvosmisleno upućuje u pravcu zaključka da je neznanje naličje 
Gregersova uvida, odnosno da je ljubavno sljepilo druga strana potrage za istinom. Slabovidnost tako nije samo simptom koji dijele stari Werle, Hedvig i pokojna majka Hjalmara Ekdala, odnosno nije tek nasljedna bolest koja povezuje dvije obitelji, nego u drami funkcionira i kao spoznajno-percepcijska boljka koja se prenosi iz generacije u generaciju, s koljena na koljeno, iz riječi u riječi.

U igri rastavljanja nasljednih linija saznajemo da Gregers nalikuje svojoj pokojnoj majci (Ibsen, 1978a, 263), kao i da osjeća odbojnost prema vlastitoj označiteljskoj vanjštini, napose prema obiteljskom imenu ${ }^{5}$, zbog čega se doima kao da se bori, da se poigramo Krležinim riječima, protiv werleštine u samom sebi. Osim što neodoljivo evocira sliku punjene patke, dvojnost unutrašnjosti i vanjštine, odnosno površine i dubine koju opisujemo ogleda se u opisu Sokratova izgleda koji Alkibijad uspoređuje s kipovima u obliku kutijica koje, kada se rasklope, otkrivaju dragocjenu ispunu. Alkibijad naime kazuje kako Sokrat nalikuje kipovima Silena „u čijoj se unutrašnjosti nalaze mala poprsja bogova, jer on je poput njih, izvana ružan, smiješan, neugledan, jadan, nespretan, groteskna figura i obični narodni komedijaš [...], no u njemu su skrivena najdivnija blaga" (Auerbach, 2004, 265; cf. Platon, 1978a, 138). Na tom tragu bliskost Platonova Sokrata i Ibsenova Gregersa Werlea očituje se - osim u neugodnoj vanjštini - i u neurednosti, osobini o kojoj se u Divljoj patki neobično mnogo raspravlja. Kao što „Sokrat nije mario za pojavni izgled [...], a njegovi su ga kritičari zvali «neoprani»»" (Guthrie, 2006, 372), o tome koliko je rafiniran Ibsenov junak dade se naslutiti iz Relingove opaske o „smrad[u]” koji Werle unosi u prostoriju (Ibsen, 1978a, 286) kao i Ginina komentara da je on oduvijek bio „smrdljiva haringa” (Ibsen, 1978a, 290) te njezine ljutnje zbog „svinj[ca]” (Ibsen, 1978a, 272) koji je ostavio iza sebe. U epizodi na početku trećeg čina doznajemo naime da je Gregres po useljenju u dom Ekdalovih pokušao zapaliti peć, ali je u neznanju zatvorio njezin otvor pa je zadimio čitavu sobu i ostavio, Gininim riječima: „o-oh [...] takav smrad" (Ibsen, 1978a, 272). U želji nadalje da ugasi vatru koja je planula,

${ }^{5}$ „GREGERS: [...] Ali kad netko ima nesreću da se zove Gregers - «Gregers» - i još «Werle»-pa jesi li ikad čuo nešto tako odvratno?

HJALMAR: Meni ne zvuči tako!

GREGERS: Ah fuj! Da čovjek zaželi da udari onoga ko se tako zove” (Ibsen, 1978a, 270). 
ulio je vodu u peć zbog čega sada, kaže očajna Gina, ,čitav pod pliva u prljavštini" (Ibsen, 1978a, 272) ${ }^{6}$.

Nasuprot Gregersu koji se, čuli smo, ne može podičiti izgledom, Rellingov opis ,ljepuškast[a]” (Ibsen, 1978a, 311) Hjalmarova lika odgovara brojnim Sokratovim sugovornicima zanosne ljepote poput primjerice Alkibijada ili Agatona. Prisjećajući se njegove pojave u mladenačkim danima, Relling kazuje kako je Hjalmar bio izuzetno privlačan: „rumen i bijel - upravo onakav momčić kakvog vole male djevojke; i jer je imao tu dušu koja lako zatreperi i nešto u glasu što plijeni srca i jer je tako lijepo znao da deklamuje stihove i misli drugih ljudi" (Ibsen, 1978a, 311). Rellingova opaska o Hjalmarovoj nekadašnjoj ljubavi prema recitaciji pjesama $^{7}$ ne potvrđuje samo njegova česta ,glumačka pretjerivanja” (Moi, 2002, 678) nego prije svega potvrđuje papagajsku ulogu koju Hjalmar zauzima u dijaloškom odnosu s Gregersom. O Gregersovoj sklonosti naime da ponavlja tuđe riječi doznajemo već na početku drugog čina, kada Hjalmar svojim ukućanima prepričava razgovor koji se odvio tijekom večere kod Werleovih, ali tako što navodi tuđe riječi odnosno duhovite komentare kao svoje. Osvrnuvši se na kratku raspravu o tokajcu koja se

${ }^{6}$ Budući da Ibsen u svojim dramama pokazuje komično lice mnogobrojnih mudrih glava, njegova se povorka učenjaka i stručnjaka u različitim znanstveno-umjetničkim zvanjima može povezati sa pripoviješću o Talesu koju spominje Platon u dijalogu Teetet. Pitajući se naime jesu li filozofi smiješni, Sokrat u Teetetu pokazuje da se u liku filozofa ogleda neobičan spoj uvida i sljepoće. Podsjetivši na pripovijest o Talesu, za kojeg se tvrdilo „da je motreći zvijezde gledao gore te [...] pao u bunar" (Platon, 1979, 47), Sokratov opis pokazuje kako je mudrac uspio sebi pribaviti „glas glupana” (Platon, 1979, 47). Kao što se tračka djevojka narugala Talesu koji je ,htio znati ono što je na nebu, a ne opaža ono što mu je sprijeda i pred nogama" (Platon, 1979, 47), tako je i Hedda Gabler izvrnula podsmijehu velike učenjake, znalce i stručnjake u čijem se okruženju zatekla. Među Ibsenovim muškim pametnjakovićima s komičnom maskom posebno se ističe stručnjak Tesman o čijem sljepilu najjasnije svjedoči navod iz Ibsenovih pripremnih bilješki: „Tesman je kratkovidan. Nosi naočale. Bože, koja prekrasna ruža! Potom gurne nos u kaktus!” (Ibsen, 1960, 163).

${ }^{7} \mathrm{Ne}$ možemo propustiti spomenuti da stari Glembay dijeli Hjalmarovu strast prema deklamaciji. Dok Hjalmar priznaje da je zaboravio pjesme koje je nekoć izvodio pred publikom, Ignjat Glembay u dijalog s Leoneom upliće stih Corneilleova don Diega rekavši mu: „Tebi sam ja htio predati sve svoje u ruke kao Corneilleov don Diego: «Ovaj mač, što ga moja ruka više ne može nositi, stavljen je u tvoju, da se osvetiš i da kazniš!»”" (Krleža, 1962, 118). Leone će očeve riječi dakako posprdno dočekati optuživši ga da je „to jedini stih što ga zna[]" (Krleža, 1962, 119) dometnuvši pritom da ga nije naučio iz knjiga jer su na njegovom noćnom ormariću uvijek stajale još nerazrezane (cf. Krleža, 1962, 118). 
ondje odvila, a u kojoj je jedan od sugovornika podučio Hjalmara kako se može prepoznati njihova razlika u godištima, Hjalmar dolazi pred suprugu i izgovara iste one riječi koje je čuo od Debelog gospodina. Istaknuvši od samog početka da se u Hjalmarovim replikama zrcale tuđe riječi, Ibsen u odnosu Gregersa i Hjalmara ocrtava hijerarhijski odnos u kojem potonji prisvaja Gregersove ideje te ponavlja njegove fraze. Prepustivši se njegovom filozofskom vođenju, Hjalmar zauzima ulogu u dijalogu koja pripada trudnim muškarcima, onima dakle koji u sebi nose zametak budućeg stvaračkog djela. Uvjeren da Hjalmar nosi ,neko svjetlo [...] u dubini svoje duše" (Ibsen, 1978a, 311), Gregers ohrabruje Hjalmara da očinsku funkciju zamijeni znanstveno-umjetničkom djelatnošću te ga potiče riječima: „,ne zaboravi da ti moraš da živiš za svoj pronalazak” (Ibsen, 1978a, 318). Predstavivši se kao fotograf sa znanstveno-umjetničkim ambicijama te kao izumitelj na pragu velikog otkrića, budućeg ,patent[a]” (Ibsen, 1978a, 295), Hjalmar ne misli o sebi da je običan zanatlija poput svoje supruge, već prije stvaratelj, demiurg:

HJALMAR: Pa valjda nisi pomislio da sam se posvetio fotografisanju samo zato da portretiram sve i svakog ko mi dođe.

GREGERS: Znam da nisi. To mi je upravo rekla i tvoja žena.

HJALMAR: Zakleo sam se: ako već žrtvujem svoje snage tako nekom zanatu, onda ga moram tako uzdići da postane prava umjetnost ili znanost. I tako sam odlučio da napravim taj čudni pronalazak (Ibsen, 1978a, 280).

Iako mu Gregers nastoji pripomoći da ,djecu svojega uma dones[e] na svijetlo dana" (Guthrie, 2006, 361), Hjalmarov roditeljski trud ostaje u konačnici i bez djela, i bez djeteta. Spoznavši mogućnost da možda nije biološki otac svoje kćeri, Hjalmar izražava bojazan da će ostati zakinut i za duhovno očinstvo te da njegov dugogodišnji rad neće donijeti plod: „Odakle ću sada da crpim snagu da bih svoj pronalazak doveo u svijet stvarnosti? Možda će on sada umrijeti u meni. A onda Gino, tvoja prošlost će biti ta koja ga je ubila" (Ibsen, 1978a, 295).

Hjalmarova se stvaralačka neproduktivnost raspoznaje upravo u Ibsenovoj igri platonističkom analogijom biološkog i duhovnog roditeljstva ${ }^{8}$,

\footnotetext{
${ }^{8}$ Istaknuvši svoje dvojno samoodređenje, Hjalmar u četvrtom činu nedvosmisleno podcrtava povezanost duhovnog i tjelesnog roditeljstva kazavši: ,ja sam zato pronalazač, hej - i otac porodice" (Ibsen, 1978a, 283).
} 
koja se u dramu čak i eksplicitno uvodi u dijalogu Gregersa i Rellinga iz kojeg doznajemo da su Hjalmara, slično kao i Jørgena Tesmana u Heddi Gabler, odgojile dvije „histerične gospođice tetke” koje je Hjalmar nazivao „duhovnim majčicama” (Ibsen, 1978a, 311). Međutim, Hjalmarova trudnoća neće naposljetku donijeti ploda: kao što možda nije biološki otac svojoj kćeri, tako vjerojatno nikada neće postati ni duhovna majka svome otkriću. Namjesto da uz pomoć Gregersa kao primalje donese na svijet vlastiti plod spoznaje, Hjalmar će samo iznova ponavljati tuđe zaključke, recitirati Gregersove riječi kao što je nekoć deklamirao stihove9 .

Slijedom Alkibijadove usporedbe Sokrata sa silenima, a posebno bliskosti koju Alkibijad uviđa sa satirom Marsijom koji je ,pomoću glazbala opčinjao ljude moći svojih usta" (Platon, 1996, 140), valja nam istaknuti problematiku učinka Sokratovih govora, odnosno istovjetnog učinka Gregersovih i Leonovih riječi. U svojoj pohvali Sokrata Alkibijad naime kazuje kako Sokratov govor djeluje poput Marsijinih skladbi koje su ,jedinstvene $u$ tome što imaju snagu da svojom božanstvenošću ovladavaju slušaocem i prokazuju one kojima su potrebni bogovi i mistična posvećenja" (Platon, 1996, 140). Ali nije Sokrat samo likom sličan rasklopljenim silenima - malo kasnije u svome govoru Alkibijad kazuje kako i Sokratove riječi imaju istovjetnu formu:

Ta ako bi tko htio slušati Sokratove govore, isprva bi mu se učinili sasvim smiješnima; takvim se riječima i izrazima izvana zaogrću kao kožom nekakva obijesna satira. Jer govori o tovarnim magarcima i nekakvim kovačima, o postolarima i kožarima, i čini se da neprestano istim riječima govori o istome tako da bi svaki neiskusan i nerazborit čovjek njegove govore ismijao. Ali ako zagleda u njih rasklopljene i prodire u njihovu nutrinu, otkrit će kao prvo da oni jedini od svih govora sadrže smisao, zatim da su prebožanstveni, da u sebi kriju premnoge dragocjenosti vrline i da se protežu na najbrojnija pitanja, zapravo na svako kojim priliči da se bavi onaj koji namjerava biti čestit i pošten (Platon, 1996, 156).

${ }^{9}$ Zanimljivo je napomenuti da se motiv ponavljanja riječi nalazi i u Gospodi Glembajevima kada u trećem činu Leone barunicu Castelli uspoređuje sa sipom, kokoši i papigom: „LEONE: [...] Ja sam sedamnaest godina gledao tko ste vi, a jutros pustili ste oko sebe tintu, wie ein Tintenfisch haben Sie sich verloren im Dunkel [izgubili ste se u tmini kao sipa]. Kao kokoš pred jastrebom, tako ste se sakrili u svoje laži! Papiga, rafinirana papiga! Sve ono što ste vi tu meni jutros govorili, to su bile moje vlastite noćašnje riječi: i ja sam sâm sebi povjerovao" (Krleža, 1962, 183). 
Pokušamo li opisati položaj koji zauzimaju Gregers i Leone, najprije ćemo uočiti da obojica nastupaju iz pozicije promatrača koji progovaraju, Pubinim riječima, ,tako odozgo iz [...] olimpske perspektive” (Krleža, 1962, 38). Da se njihove riječi formalno mogu usporediti s rasklopljenim silenima, odnosno kožom nekakva obijesna satira, najjasnije svjedoči Hedvigin komentar u kojem majci kazuje da je „čitavo vrijeme [...] izgledalo kao da [Gregers] misli nešto drugo od onog što govori”" (Ibsen, 1978a, 270).

Oslonimo li se u analizi na kritičku recepciju Glembajevih koja ne previđa Krležine ,jezičko-stilske akrobacije” (Pavlić, 2019, 128), kao ni značaj koji u drami zauzima razumijevanje prava i pravičnosti, možemo jasnije uvidjeti kako ljubav prema istini u Ibsenovih i Krležinih junaka uvjetuje specifičan odnos spram jezika. Naime, od prvog prizora u kojem ga Angelika upozorava da „mnogo pretjeruje[] u riječima” (Krleža, 1962, 14), Leone se predstavlja kao „neobično duhovit kozer” (Krleža, 1962, 14). Njegovi sugovornici redom se slažu s Pubom da njegov ,ironični stav prema svemu djeluje kadšto doista neumjesno" (Krleža, 1962, 31), a njegov govor opetovano se u drami označava kao drugima neshvatljiv. Priznavši da ga uopće „ne razumije[]”, doktor Altman u Leoneovu načinu govora raspoznaje psihopataološku crtu: ,[t] $]$ i govoriš tako perverzno, kao da si kokainist! Kako se može o ovakvim stvarima govoriti tako, bogami, paranoidno?" (Krleža, 1962, 64). S druge strane, jezik Gregersa Werlea prepun je „opskurnih metafora” (cf. Moi, 2002, 669) koje drugi likovi u drami ne uspijevaju odgonetnuti.

HEDVIG: Nešto ću ti reći, majko - mislim da je time htio da kaže nešto drugo.

GINA: A šta bi to moglo biti?

HEDVIG: To ne znam, ali čitavo vrijeme je izgledalo kao da misli nešto drugo od onoga što govori.

GINA: Misliš? Da, bilo je čudno (Ibsen, 1978a, 270).

Jednako dakle kao i za Gregersa - za kojeg Hjalmar kaže „tu ti ja ne razumijem ni jedno slovo" (Ibsen, 1978a, 270) - tkogod je stupio u dijalog s Leoneom, prije ili kasnije ustvrdit će - poput barunice Castelli u trećem činu: „Ja ne razumijem ni jedne jedine riječi!” (Krleža, 1962, 160).

Završna tragedija u Ibsenovu djelu, koja proizlazi iz činjenice da je Hedvig doslovno shvatila očeve riječi, zrcali se u kobnom nesporazumu 
Canjegove i Leonea: Fanika Canjeg oduzela je život sebi i svome djetetu nakon razgovora s Leoneom koji joj je izložio svoje mišljenje o mogućem izlazu iz situacije u kojoj se zatekla: „Ako vi od ovih dobrotvora očekujete svoj spas, onda vam je bolje, da odmah skočite kroz prozor!" (Krleža, 1962, 71). Pri tome naravno Leonu nije bilo ni nakraj pameti da će nesretna žena doista poslušati prijedlog koji joj je iznio u retoričkom zanosu. Možemo zaključiti dakle da razlog suicida u objema dramama proizlazi iz nerazumijevanja jezične djelatnosti - ono što Toril Moi kazuje o Hedvig, može se primijeniti i na mladu ženu iz Krležine drame: ona naprosto „nije imala iskustva s ljudima koji govore u zagonetkama” (Moi, 2002, 669). Kada pak stari Glembay izravno optuži Leonea da je Canjegovu „perfidno natjerao u smrt" (Krleža, 1962, 123), u njegovoj bijesnoj replici izlazi na vidjelo ključna poveznica između govora Gregersa Werlea - koji sebe uspoređuje sa psom - i Leonea Glembaja: „Ti si luđak! Ti nemaš nikakve predodžbe o značenju svojih riječi! Znaš li ti uopće što ti laješ?” (Krleža, 1962, 124) ${ }^{10}$.

U drugoj knjizi Države Platon filozofe uspoređuje upravo sa psima koji u svome ponašanju očutuju izrazitu ,ljubav prema znanju” (Platon, 2002, 56) ${ }^{11}$. Tvrdeći kako pas ima „nečeg mudroljubivog u svojoj prirodi” (Platon, 2002, 56), Sokratova usporedba povezuje animalističke metafore koje nalazimo u Ibsenovu i Krležinu dramskom tekstu. Ustvrdivši da ga je zadesila nesreća „da igra ulogu Gregersa Werlea”, tegotnu ulogu koju smo prethodno označili kao ulogu lovca na istinu, onoga koji istinu ljubi i goni, Gregers poput lovačkog psa svugdje prati njezin trag i hoće je pod svaku cijenu izvući na površinu (Ibsen, 1978a, 77) ${ }^{12}$. Nakon što ga je pak Hjalmar

${ }^{10}$ Jedanko će tako Dr. Altman upozoriti Leonea da griješi misleći da su njegove riječi prozirnije od tuđih: „Ako ti misliš, da ovo, što ti govoriš, nije prekriveno crnom krpom, ti se onda očito varaš dragi moj!” (Krleža, 1962, 149).

${ }^{11}$ Budući da psi vole one koje poznaju, Sokrat zaključuje da se u njihovu držanju dade raspoznati „ljubav prema znanju”, koja se ogleda „u tome da se razlikuje poznato od nepoznatog, domaće od tuđinskog” (Platon, 2002, 56).

${ }^{12}$ Kako ističe Berislav Podrug, lov se u Platonovu djelu često rabi kao metafora za filozofiranje: „Tako se u njegovim filozofijskim razgovorima nerijetko govori o sveopćem lovu na biće (v. Gorg. 500d; Phaid. 66c; Thaet. 198a). Time Platonov koncept Erosa biva i na ovoj ravni, kao i na onoj bitkovnoj i vremenskoj, izrazito dinamičan. Tko nešto voli, odnosno tko nešto lovi, ne posjeduje to, već istim biva privučen i pokrenut, hvatajući ga, svim sredstvima na njega smjerajući i ciljajući. Ljubav i lov jednako proizlaze iz nedostatka, očitujući svojim karakterističnim ustrojstvom težnju za stjecanjem i ispunjenjem. Eros je od majke naslijedio to da je svagda siromašan i u najvećoj mjeri potrebit, zauvijek lišen 
priupitao „da nisi Gregers Werle, što bi htio biti?”, Gregersov odgovor nedvosmisleno upućuje u smjeru analogije lovine $\mathrm{i}$ istine:

GREGERS: Kad bih mogao birati, najradije bih bio jedan spretan pas!

GINA: Pas?!

HEDVIG (Nehotice): Valjda ne.

GREGERS: Da, jedan čudesno spretan pas, koji roni na dno za divljim patkama kad potonu i zapletu se u mulju na dnu, u morsku travu (Ibsen, 1978a, 77).

Preuzevši zadaću lovačkog psa koji u ustima donosi istinu, Gregersov lavež posebno jasno odjekuje u Krležinim didaskalijama u kojima se Leone na više mjesta opisuje u terminima krvoločne životinje - štoviše, stari će Glembay za njegove riječi kazati da su to „daniellijevski zubi u meni”" (Krleža, 1962, 115). U trećem činu Krleža naznačuje kako Leone ,hoda sobom kao uznemirena zvijer" (Krleža, 1962, 154), a on će u razgovoru s Angelikom svoj sukob s ocem usporediti upravo s borbom čagljeva, životinje koja i pripada rodu pasa: ,ja sam se zagrizao u njega kao šakal u šakala: to se u nama grizla glembajevska krv!" (Ibsen, 1978a, 179).

Da je drugo krilo istine doista središnja preokupacija Divlje patke dade se raspoznati u Ibsenovu pomno osmišljenom prostornom rasporedu u kojem se ističe začudan pozadinski prostor kao druga pozornica. U stanu Ekdalovih - koji funkcionira istodobno kao obiteljski dom i Ginino i Hjalmarovo radno mjesto, njihov fotografski studio - uz sobičak u kojem stanuje stari Ekdal krije se još i tajni prostor. Usred njihova domaćinstva smjestio se dakle svijet divljine, replika daljine i tuđine Høidala odnosno šumskih predjela u kojemu je stari Ekdal nekoć uživao u lovu. Osmišljen da nadomjesti lovište, tavanski prostor Ekdalovih nadaje se, kako Relling razjašnjava, kao ograđeni prostor fikcije u kojem se sve pretvara u nešto drugo, u kojem stari Ekdal nastupa poput glumca u predstavi:

doma, zaštite i skloništa. S druge strane, od oca mu je pripalo to da je stalno u potrazi za probitkom i dobitkom, kao spretan, vješt i lukav poduzetnik i lovac. Tako i sam heroj prema Platonovom Kratilu nastaje vjerojatno od riječi «eros», a tko je spretan na tom polju odnosno u tom pogledu, taj je mudrac ili dijalektičar (398c7-e5)" (Podrug, 2016, 242-243). 
Četiri-pet osušenih božićnih jelki koje je tamo poredao, za njega su isto što i velika, svježa hoidalska šuma. Pijetao i kokoši su mu tetrijebi i tetrebice u borovim vrhovima; zečići i kunići što skakuću po tavanu su medvjedi, za koje je toliko vezan, taj hrabri starac-prirodnjak (Ibsen, 1978a, 312).

Iako pokraj kulise starih božićnih jelki obitavaju kojekakve životinje - kokoši, golubovi pismonoše i golubovi gušani te kunići, tavan je prije svega dom divlje patke. Budući da se Ekdalov dom nalazi u potkrovlju, galerija predstavlja njegovo drugo krilo, krilo u kojem boravi životinja koju je ranila lovačka sačmarica staroga Werlea, zbog čega više ne može letjeti. Kako saznajemo iz didaskalijskih napomena, podjela na gornji i donji prostor ponavlja se i u prostoru galerije u kojemu postoje dvije etaže: donja za kokoši, kuniće i patku, a gornja za golubove koji imaju svoje sanduke pod samim krovom. Osim toga, pregrada koja dijeli dva prostora i sama je dvojna, preciznije rečeno, vrata su dvokrilna, a zavjesa je dvovrsna. Prva vrata koja vode na tavan klizna su vrata, a u didaskalijama stoji kako Hjalmar i Ekdal „odlaze do zadnjeg zida i guraju svaki po jedno krilo dvokrilnih vrata" (Ibsen, 1978a, 266). Rastvorivši ih, Hjalmar još poteže konop koji povlači zavjesu - unutrašnjost koje se „sastoji od starog platna za jedra. Gornji dio je napravljen od komada nategnute ribarske mreže" (Ibsen, 1978a, 274). U posljednjem dijelu didaskalijskog opisa koji glasi ,[o]tvori na krovu kroz koje jasna mjesečina osvjetljava pojedine dijelove prostorije, dok je sve drugo u tami” (Ibsen, 1978a, 267) ocrtava se mračna dimenzija u unutrašnjosti prostorije, njezina tamna strana u kojoj se, ako se gleda iz određenog kuta, može uočiti divlja patka.

Iako se u ibsenološkim raspravama neobičan prostor u domu obitelji Ekdal povezivao sa znanstvenim laboratorijem (cf. Zwart, 2000), dok su se životinje koje ondje obitavaju dovodile u vezu s primjerima životinjskih vrsta koje u svojoj teoriji evolucije navodi Charles Darwin (cf. Aarseth, 2005; Wærp, 2020) ${ }^{13}$, na tragu dosad izložene teze o Platonovu intertekstu

${ }^{13}$ Slijedom niza usporedbi dramskih likova i životinjskih vrsta koji zatječemo u Divljoj patki, Asbjorn Aarseth istražio je utjecaj Darwinovih znanstevnih ideja na Ibsenovo djelo, posebno se usredotočivši pritom na pitanje domestikacije. Istaknuvši kako se u Darwinovoj studiji $O$ podrijetlu vrsta, zečevi, kokoši, patke i golubovi - dakle životinje koje zatječemo na tavanu Ekdalovih - spominju upravo u kontekstu pripitomljavanja životinja, Aarseth $(2005,7)$ izvodi zaključak kako Ibsen temu udomaćivanja rabi kako bi opisao degeneraciju. 
Ibsenove drame, pokušat ćemo dokazati da je mali zoološki vrt u domu obitelji Ekdal izgrađen takoreći po nacrtu i modelu golubinjaka koje Sokrat opisuje u Platonovu dijalogu Teetet.

Kako bi naime pojasnio način na koji raspolažemo znanjem, Sokrat nas poziva da zamislimo u ,svakoj duši [...] neki golubinjak svakojakih ptica, jedne u jatima odijeljene od ostalih, druge u malim grupama, a neke same gdje lete kroz sve druge kuda god im se prohtje" (Platon, 1979, 78). Usporedivši dušu s kavezom za ptice u kojem umjesto ptica zrakom lete znanja, Sokrat pokušava oslikati dvojnu prirodu znanja. Sokrat stoga uvodi razliku između znanja koje posjedujemo i znanja koje imamo, a koju oprimjeruje slikom osobe koja posjeduje haljinu koju ne želi nositi: ,ako netko kupi haljinu i postaje gospodar a ne bi je nosio, rekli bismo za njega da je nema ali je posjeduje" (Platon, 1979, 77). Na isti način prema Sokratu netko može nemati znanje, a da ga pritom posjeduje:

SOKRAT: Gledaj sada da li je moguće da tako nema znanje i onaj koji ga posjeduje, nego samo posjeduje kao što ako bi netko divlje ptice, golubove ili nešto drugo ulovio i kod kuće hranio u napravljenom golubinjaku. Na neki naime način mogli bismo za toga reći da ptice uvijek ima jer ih posjeduje. Zar ne?

TEETET: Da.

SOKRAT: A na drugi način da nijednu nema, već mu je dopala vlast nad njima pošto ih je podložio u vlastitom ograđenom prostoru, te ih može uzeti i zadržati kad zaželi i može uhvatiti i opet pustiti onu pticu koju hoće. To mu je moguće činiti koliko god puta mu se svidi (Platon, 1979, 77-78).

Kao što smo pokušali pokazati slijedom Platonove metafore znanja kao ptica, Krležini i Ibsenovi ljubitelji istine u isto vrijeme posjeduju znanje o istini, a nemaju ga. Budući da se na tavanu Ekdalovih životinje ne ubijaju, nego se hvataju radi užitka, razonode i sporta, izdvojeno područje na kojem se odvija kućni lov dade se usporediti s ograđenim prostorom o kojem Sokrat govori, a u kojem se ptice po želji hvataju i opet puštaju da lete. Ne predstavlja li, da krenemo prema zaključku, zatvorena kutija na stropu obiteljskog doma najočitiju Ibsenovu metaforu drugosti unutar

Suprotstavljajući se Aarsethovom tumačenju prema kojem domestikacija sugerira zaborav autentičnog života, Lisbeth P. Wærp tvrdi da se na tavanu Ekdalovih odvija borba za opstanak između životinja koje su pripitomljene i životinja koje nisu. Tavan tako predstavlja, prema autoričinu mišljenju, ,scensku metaforu života odnosno egzistencije kao takve, kao borbe za opstanak" (Wærp, 2020, 17). 
vlastita četiri zida, metaforu druge pozornice znanja? Nije li prostor koji se u drami naziva morskim bezdanom (cf. Ibsen, 1978a, 280), a u kojem obitava divlja patka, metafora upravo bezdana jezične reprezentacije drugog prostora u riječima koji Hedvig zamjećuje u Gregersovom govoru i u kojem naslućuje drugo krilo označiteljske mreže? Nije li Leone Glembay - za kojeg Željka Matijašević pokazuje da je „glasnogovornik druge pozornice” odnosno „glasnogovornik svijeta u negativu” (cf. Matijašević, 2011/2012) - u tom smislu nasljedovatelj Sokratova položaja „koji na vidjelo iznosi nemogući odnos između jezika i istine" (Ronen, 2018, 37), diskursa koji razotkriva raskol, pregradu u polju simboličkog znanja, rascjep zbog kojeg u konačnici ni sami nismo sigurni jesu li Leoneove i Gregersove optužbe istinite ili je sve bila samo - patka?

\section{Literatura}

Aarseth, A. (2005). Ibsen and Darwin: A Reading of The Wild Duck. „Modern Drama” no. 48 (1), str. 1-10. https://doi.org/10.3138/md.48.1.1.

Arbanas, G., Kreho, D. (2019). Leone Glembay - psihijatrijska i forenzička razmatranja književnog lika. „Liječnički vjesnik” vol. 141, br. 1-2, str. 40-44. https://doi. org/10.26800/LV-141-1-2-7.

Auerbach, E. (2004). Mimeza. Prikaz zbilje u zapadnoeuropskoj književnosti. Zagreb: Hena com.

Durbach, E. (2009). Ibsen's Evangelical Detective: Evidence and Proof in The Wild Duck. „Scandinavian-Canadian Studies/Études Scandinaves au Canada” vol. 18, str. 44-54.

Guthrie, W. K. C. (2006). Povijest grčke filozofije. Sofisti - Sokrat. Prev. J. Bubalo, B. Malić, Z. Posinovec. Zagreb: Naklada Jurčić.

Ibsen, H. (1960). Hedda Gabler. U: Playwrights on Playwriting. The Meaning and Making of Moderm Drama from Ibsen to Ionesco. Ed. T. Cole. London: Macgibbon \& Kee, str. 156-170.

Ibsen, H. (1978a). Divlja patka. U: Drame. Prev. Z. Mehmedbašić. Sarajevo: Veselin Masleša, str. 237-324.

Ibsen, H. (1978b). The Complete Major Prose Plays. Prev. R. Fjelde. New York: New American Library.

Ibsen, H. (1987). Divlja patka. Prev. A. Katušić Balen. [Rukopis].

Klajn, H. (1968). Gospoda Glembajevi u svetlu dubinske psihologije. „Forum: mjesečnik Razreda za književnost Hrvatske akademije znanosti i umjetnosti” vol. 15, br. 1 , str. $103-135$.

Krleža, M. (1962). Glembajevi. Drame. Zagreb: Zora. 
Lacan, J. (2007). The Seminar of Jacques Lacan: The Other Side of Psychoanalysis. New York: W. W. Norton \& Company.

Moi, T. (2002). ,It was as if he meant something different from what he said-all the time”: Language, Metaphysics and the Everyday in The Wild Duck. „New Literary History" vol. 33, br. 4, str. 655-686. https://doi.org/10.1353/nlh.2002.0042.

Matijašević, Ž. (2011/2012). Koja je prava boja nečiste krvi: Gospoda Glembajevi. „Drama - Slovensko narodno gledališče” br. 131.

http://www.ffzg.unizg.hr/kompk/index.php?show=page.php\&idPage=27. 15.12.2020

Pavlić, G. (2019). Glembajevi - dvojno čitanje. Zagreb: Akademija dramske umjetnosti-Hrvatska sveučilišna naklada.

Platon (1979). Teetet ili O znanju: istraživački dijalog; Fileb ili O nasladi: etički dijalog. Prev. M. Sironić, V. Gortan. Zagreb: Naprijed.

Platon (1996). Simpozij. U: Eros i Filija. Prev. Z. Dukat. Zagreb: Demetra, str. 20-163.

Platon (2002). Država. Prev. A. Vilhar. Beograd: Kultura.

Podrug, B. (2016). Platonov Simpozij: Eros kao počelo filozofije. Zagreb: Demetra.

Ronen, R. (2018). Lacan with Philosophers. Toronto: University of Toronto Press. https://doi.org/10.3138/9781487516079.

Szlezàk, T. A. (2000). Čitati Platona. Zagreb: Naklada Jesenski i Turk.

Vidan, I. (1975). Ciklus o Glembajevima u svom evropskom kontekstu. U: Tekstovi u kontekstu: odjeci i odnosi u novijoj književnosti. Zagreb: Liber.

Wærp, L. P. (2020). The Struggle for Existence. Ibsen's The Wild Duck (Vildanden, 1884). „Ibsen Studies” 20 (1), 3-36. https://doi.org/10.1080/15021866.2020.175 7303.

Zupančič, A. (2006) When Surplus Enjoyment Meets Surplus Value. U: Jacques Lacan and the Other Side of Psychoanalysis. Eds J. Clemens, R. Grigg. Durham, N.C.: Duke University Press, str. 155-178. https://doi.org/10.1215/9780822387602-009.

Zwart, H. A. E. (2000). The Birth of a Research Animal: Ibsen's The Wild Duck and the Origin of a New Animal Science. „Environmental Values” 9 (1), str. 91-108. https://doi.org/10.3197/096327100129341994. 